\title{
Minor Programs in the Geospatial Domain - Referencing the GIScience \& Technology Body of Knowledge
}

\author{
Adrijana Carl and Josef Strobl2 \\ 1 German University of Technology in Oman \\ 2 University of Salzburg, Austria
}

\begin{abstract}
In this paper we analyse numerous Minor programs in GIScience \& Technology (GIS\&T) / Spatial Sciences offered worldwide as secondary subjects complementing Major programs at BSC and MSc level. The objectives are the identification of core contents and qualifications/competencies related to $\mathrm{Gl}$, and their respective weights measured in terms of credit points. The information derived provides a framework for the comparison of Minors at undergraduate and graduate levels, and serves as a basis for curriculum design of a Minor in GIS. The study draws upon and complements the recent activities of UCGIS to redesign the main reference document for curriculum design, GIS\&T Body of Knowledge BoK2, as well as the European initiative GI-N2K, which analysed workforce demand in GIS\&T.
\end{abstract}

\section{Keywords:}

GIS Minor, Zusatzstudium, GIS\&T BoK, BoK2 project, curriculum design, GI-N2K

\section{Introduction}

Minors enable students to broaden the scope of their primary educational program ${ }^{1}$ (Major) to fit with their interests and the qualifications they require. Numerous Minors in GIS are offered by universities across the globe as secondary subjects complementing a great variety of Major programs at undergraduate and graduate levels (Strobl, 2008). GIS Minor programs are aimed at students who wish to acquire a foundation in Geographic Information Science and Technology (GIS\&T). These Minors often focus on geographic representation, analysis methods, mapping, or geospatial techniques like GPS and remote sensing (see e.g. Verfaillie

\footnotetext{
1 Throughout this article, we use the US spelling "program" as more consistent with the terms Major and Minor. It is also the spelling used for the original internet search. In German, a Minor program is called Studienergänzung, Nebenfach or Zusatzstudium ("Studienergaenzungen und Schwerpunkte", 2016). Both of these terms were used in the internet search.
} 
et al., 2012). Such spatial competencies are considered valuable assets for graduates entering the job market ("Minor in GIS at the National University of Singapore", 2013).

Comparing GIS Minors is challenging due to the diversity of academic environments, as seen most clearly in the different weights and learning outcomes. Unlike the BSc/MSc programs, GIS Minors lack a framework for comparison or standardized core content reflected in learning outcomes. We propose to use the Geographic Information Science \& Technology Body of Knowledge (GIS\&T BoK) reference document (DiBiase et al., 2006) for curriculum design of a GIS Minor.

For over two decades, experts from academia and industry have put considerable effort into the development of model curricula for the GIS\&T domain. The GIS\&T BoK is a landmark achievement that emerged from these efforts. It was created under the guidance of the University Consortium for Geographic Information Science (UCGIS) with the objective of defining the then-current state of the body of knowledge that would help reduce the gap between GIS education and industry needs (DiBiase et al., 2006). The GIS\&T BoK is meant to be used as a baseline for developers to create new curricula and to benchmark existing ones at all levels of higher and continuing education (see e.g. DeMers, 2009; Prager, 2012; Prager \& Plewe, 2009).

The GIS\&T knowledge in the BoK is organized hierarchically into 10 Knowledge Areas. Each Knowledge Area consists of a set of Units that are further subdivided into Topics. Each Topic is assigned a set of related learning objectives. In total, BoK identifies 329 Topics, together with a list of 1,660 learning objectives.

The highly dynamic nature of the GIS\&T field and development trends (see e.g. Norris, 2015, or Goodchild, 2010) and corresponding requirements of the job market raise the question, however, of whether GIS\&T BoK can still be used effectively as a baseline. Recently, several major initiatives were launched to revise the GIS\&T BoK (hereafter referred to as BoK). The UCGIS in the U.S. initiated the BoK2 project, with the aim of updating the content of the BoK itself (http://ucgis.org/project-group/gist-bodyknowledge-project). Parallel to BoK2, several European initiatives have worked on the same task, but with the focus on a demand-oriented revision of the content and format of BoK (see e.g. "Geographic Information Science (GIS) minor", 2016). These initiatives recently merged into the "Geographic Information: Need to Know" (GI-N2K) European network project (http://www.gi-n2k.eu/). Two publications offer an excellent overview and review of activities related to these initiatives, as well as the current status of the BoK revision. The first is John Wilson's report on the assessment of the BoK content from the perspective of GIS\&T researchers and practitioners, who identified the extent of the revision required and its level of urgency (Wilson, 2014). The second is the paper by Gudrun Wallentin, Barbara Hofer and Christoph Traun (2015), which also provides input for the revision of the BoK based on the assessment of workforce demands.

This study draws upon and complements the recent activities of the UCGIS to redesign the main reference document for curriculum design, i.e. GIS\&T BoK, as well as the European GI-N2K initiative which analysed the workforce demand in GIS\&T. Using the GIS\&T BoK as a reference document, our objective is to identify core components and qualifications/competencies related to GIS\&T, while considering proposed updates for the 
content of the GIS\&T BoK. In the remainder of this paper, we first define a set of attributes to describe GIS Minors and then use these to define a set of criteria for the comparison of Minors. These derived criteria resulted in a set of topics that can serve as the basis for curriculum design of Minors.

\section{Framework for analysis of GIS Minors}

In order to gather background information and establish a baseline for our empirical study, we conducted literature research and document analysis (Bowen, 2009). A website survey provided information about GIS Minor programs for analysis. Documents serve as sources of data and can be classified as personal/official and private/public. The quality-assessment criteria for the documents include: authenticity - evidence of document's genuine and unquestionable origin; credibility - document is free from error and distortion; meaning document is clear and comprehensible; representativeness - document is typical of its kind; or to what extent is it untypical and why? Documents can be analogue or digital. It is important to keep all four of these criteria in mind for virtual documents on the Internet such as websites, blogs and postings (Bryman, 2012).

\section{Metrics: Credits}

In most academic environments, the value of an academic program or an individual course is expressed in credits (also known as credit hours, credit points or units). A credit is a measure for learning outcomes and workload, i.e. what students are expected to know and be able to do within an allocated period of time (ERASMUS+, 2015). Hence, a standardized credit system monitors student workload and academic progress, helps set tuition fees, and facilitates student transfers to other institutions of Higher education.

The majority of European countries adopted and implemented the European Credit Transfer System (ECTS) through the Bologna Process, which was established in 1999. ECTS is "a learner-centered system for credit accumulation and transfer, based on the principle of transparency of learning, teaching and assessment processes. Its objective is to facilitate the planning, delivery and evaluation of study programs and student mobility by recognizing learning achievements and qualifications and periods of learning" (ERASMUS+, 2015, p. 11). According to the ECTS, a full-time student needs to complete 60 ECTS credits per academic year, equivalent to 1,500 to 1,800 hours of study. Study programs in Europe amount to 180240 ECTS credits for Bachelor's degrees and 60-120 for Master's programs.

American, Canadian and Australian academic institutions have been using credit systems for a long time. In the U.S., for example, a credit unit is the sum of actual classroom hours (e.g. lectures, labs, seminars) and hours of independent study (USNEI, 2008). The definition of a credit may differ from one university to another. For example, at the University of California in Santa Barbara, 1 credit equals 3 hours of student work; students take an average 15 credits per quarter and must earn about 180 credits to complete an undergraduate program (Kuhn, 2015). Canada and Australia do not have standard credit systems, and what constitutes a credit varies between universities and provinces (masterportal, 2015). 
Table 1: An overview of properties of different credit systems (* applies to the whole of an individual university, i.e. is a university-wide system)

\begin{tabular}{|l|l|l|l|l|l|l|}
\hline $\begin{array}{l}\text { Credit } \\
\text { System }\end{array}$ & $\begin{array}{l}\text { Unit } \\
\text { name }\end{array}$ & $\begin{array}{l}\text { Units } \\
\text { per } \\
\text { semester }\end{array}$ & $\begin{array}{l}\text { Units } \\
\text { BSc }\end{array}$ & $\begin{array}{l}\text { Units } \\
\text { MSc }\end{array}$ & $\begin{array}{l}\text { Workload } \\
\text { per unit }\end{array}$ & $\begin{array}{l}1 \text { unit value in } \\
\text { ECTS }\end{array}$ \\
\hline ECTS & credit & 30 & $180-240$ & $60-120$ & $25-30$ hours & 1 \\
\hline $\begin{array}{l}\text { USA* } \\
\text { Canada* }\end{array}$ & credit & $12-15$ & $130-180$ & $30-64$ & $\sim 3$ hours/week & $\sim 2$ \\
\hline Singapore & $\begin{array}{l}\text { module } \\
\text { credit }\end{array}$ & $15-25$ & $\sim 100$ & $120-160$ & 2.5 hours/week & 0.8 \\
\hline Australia* & unit & $\sim 18$ & $72-144$ & $\begin{array}{l}\text { (no } \\
\text { value } \\
\text { found) }\end{array}$ & (no value found) & 1.667 \\
\hline
\end{tabular}

The summary of credit systems in Table 1 (at national or university level) provides a basis for comparing the GIS Minors in this study.

\section{Selection criteria for Minor programs}

An initial Google search for "GIS Minor programs" returned 33,100,000 results (March 2015). These included geographically-spread Minors with a focus on GIS per se as well as Minors with specific GIS applications (e.g. GIS in ecology, urban planning, forestry etc.). In the second instance, we focused on "pure" GIS Minors, i.e. without a particular field of application, to allow for comparison of similar programs. Keywords used in this search were GIS, Geographic Information Systems, Geographic Information Science, Geographic Information Science \& Systems, and Spatial Sciences. This refined search resulted in 100+ similar Minors, many of which were offered in the USA.

An analysis of the content of the documents for these programs available on the internet provided insights into the kinds of information used for the description of Minors. From this information, a set of criteria was derived, which led to a subset of programs that reflect the diversity of academic environments in which the Minor programs are offered. These criteria are:

- Name of a program: should include one of the following terms:

GIS | Geographic Information Systems | Geographic Information Science | Geographic Information Science \& Systems | Spatial Sciences

- Geographic location: representative of different academic environments in various parts of the world

- Individual programs: i.e. those listed on university websites under category "Minor", which are therefore easier to find

- Documentation about the program should be available on the Internet, credible and of good quality.

Table 2 summarizes the data collected for each program. The final list of programs selected for our study (the sample) is given in 2 Analysis of the sample programs 


\section{Documentation}

All documents were accessible online, either on official university websites (i.e., virtual documents) or as downloadable (pdf) documents from those websites. Most documentation was current, as indicated by academic or calendar year and/or date of the last update of a website. Documents appeared authentic: we had no reason to question their origin or genuine legitimacy (e.g. emblem or logo, corporate design). Their clarity and comprehensiveness varied, especially regarding credit system details.

\section{Academic environment for Minors}

An individual Minor is a formal study program type commonly found on official university websites. This is the case not only for the sample programs (Fehler! Verweisquelle konnte nicht gefunden werden.) but also for other programs we initially surveyed.

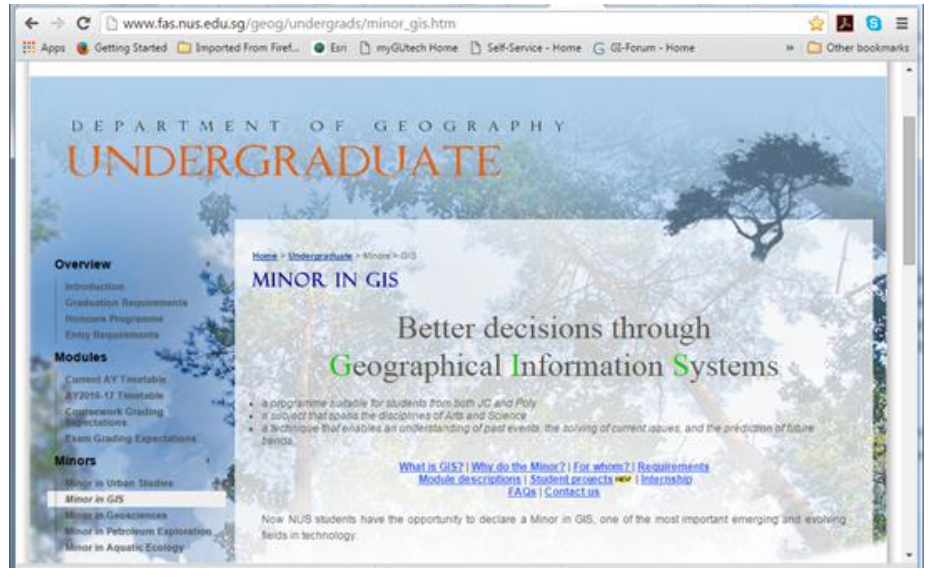

Figure 1: Official website of the Minor in GIS offered at the National University of Singapore

Table 2: Attributes describing individual GIS Minors

\begin{tabular}{|l|l|}
\hline Attribute & Description \\
\hline Program name & Name of the program \\
\hline Academic level & $\begin{array}{l}\text { Offered at undergraduate (BSc), } \\
\text { graduate (MSc / PhD), or both levels }\end{array}$ \\
\hline Credit points & $\begin{array}{l}\text { Total number of credit points required for successful completion of the } \\
\text { program }\end{array}$ \\
\hline Credit point system & Credit point system, e.g. ECTS vs. university-dependent \\
\hline University name & University at which the program is offered \\
\hline Department name & Department which offers the program \\
\hline URL & URL of the program-description document \\
\hline Access date for URL & Date when the website (URL) was last accessed \\
\hline Update date for URL & Date when the website (URL) was last updated \\
\hline Program content URL & URL with the program curriculum \\
\hline
\end{tabular}




\section{Analysis of the sample programs}

\section{Documentation}

All documents were accessible online, either on official university websites (i.e., virtual documents) or as downloadable (pdf) documents from those websites. Most documentation was current, as indicated by academic or calendar year and/or date of the last update of a website. Documents appeared authentic: we had no reason to question their origin or genuine legitimacy (e.g. emblem or logo, corporate design). Their clarity and comprehensiveness varied, especially regarding credit system details.

\section{Academic environment for Minors}

An individual Minor is a formal study program type commonly found on official university websites. This is the case not only for the sample programs (Fehler! Verweisquelle konnte nicht gefunden werden.) but also for other programs we initially surveyed.

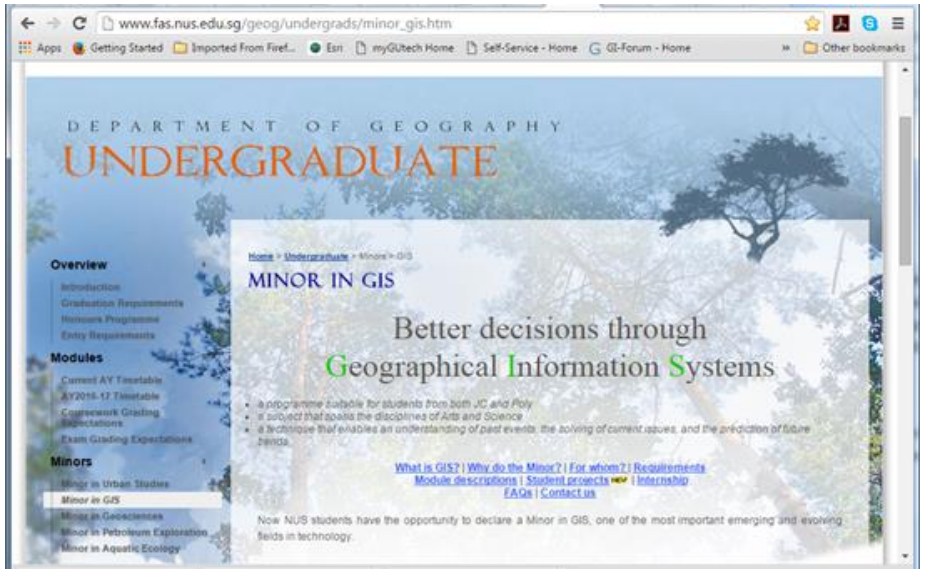

Figure 1: Official website of the Minor in GIS offered at the National University of Singapore 


\section{Car \& Strobl}

Table 3: GIS Minors selected for the study (* refers to a university-dependent credit system)

\begin{tabular}{|c|c|c|c|c|c|c|c|}
\hline Program name & $\begin{array}{l}\text { Academic } \\
\text { level (Undergraduate / } \\
\text { Graduate) }\end{array}$ & $\begin{array}{l}\text { Credit } \\
\text { value }\end{array}$ & $\begin{array}{l}\text { Credit } \\
\text { System }\end{array}$ & Certificate & University & Department & Country \\
\hline $\begin{array}{l}\text { Minor in Geographic } \\
\text { Information Systems }\end{array}$ & undergraduate & 24 & $\mathrm{MC}$ & yes & $\begin{array}{l}\text { National University of } \\
\text { Singapore }\end{array}$ & Department of Geography & Singapore \\
\hline $\begin{array}{l}\text { Minor in Geographic } \\
\text { Information Science } \\
\text { and Technology }\end{array}$ & both & & US credit* & yes & $\begin{array}{l}\text { University of California, } \\
\text { Berkeley }\end{array}$ & $\begin{array}{l}\text { Department of } \\
\text { Environmental Science, } \\
\text { Policy, and Management }\end{array}$ & USA \\
\hline $\begin{array}{l}\text { UCSB Academic } \\
\text { Minor in Spatial } \\
\text { Studies }\end{array}$ & undergraduate & 24 & US credit* & yes & $\begin{array}{l}\text { University of California, } \\
\text { Santa Barbara }\end{array}$ & Center for Spatial Studies & USA \\
\hline $\begin{array}{l}\text { USC Spatial Studies } \\
\text { Minor }\end{array}$ & undergraduate & 20 & US credit* & yes & $\begin{array}{l}\text { University of Southern } \\
\text { California }\end{array}$ & $\begin{array}{l}\text { Dornsife College of } \\
\text { Letters - Spatial Sciences } \\
\text { Institute }\end{array}$ & USA \\
\hline $\begin{array}{l}\text { UoR Spatial Studies } \\
\text { Minor }\end{array}$ & undergraduate & 24 & US credit* & yes & University of Redlands & College of Arts \& Sciences & USA \\
\hline $\begin{array}{l}\text { PennState Geographic } \\
\text { Information Science } \\
\text { (GIS) Minor }\end{array}$ & undergraduate & 18 & US credit* & yes & $\begin{array}{l}\text { Pennsylvania State } \\
\text { University (Penn State) }\end{array}$ & $\begin{array}{l}\text { College of Earth and } \\
\text { Mineral Sciences, } \\
\text { Department of Geography }\end{array}$ & USA \\
\hline $\begin{array}{l}\text { Minor program in } \\
\text { Geographic } \\
\text { Information Science } \\
(\mathrm{BSc})(\mathrm{BA})\end{array}$ & undergraduate & 4 & $\begin{array}{l}\text { Canadian } \\
\text { credit* }\end{array}$ & & $\begin{array}{l}\text { University of Toronto } \\
\text { Scarborough }\end{array}$ & $\begin{array}{l}\text { Department of Human } \\
\text { Geography }\end{array}$ & Canada \\
\hline McMU GIS Minor & undergraduate & 24 & $\begin{array}{l}\text { Canadian } \\
\text { credit* }\end{array}$ & yes & $\begin{array}{l}\text { McMaster University, } \\
\text { Hamilton }\end{array}$ & $\begin{array}{l}\text { School of Geography and } \\
\text { Earth Sciences }\end{array}$ & Canada \\
\hline $\begin{array}{l}\text { Joint National } \\
\text { Geoinformation } \\
\text { Minor }\end{array}$ & both & 30 & ECTS & yes & $\begin{array}{l}\text { Free University } \\
\text { Amsterdam }\end{array}$ & $\begin{array}{l}\text { Faculty of Earth and Life } \\
\text { Sciences }\end{array}$ & $\begin{array}{l}\text { Netherlan } \\
\text { ds }\end{array}$ \\
\hline $\begin{array}{l}\text { Geographische } \\
\text { Informationssysteme } \\
\text { (GIS) }\end{array}$ & both & 24 & ECTS & yes & University of Salzburg & $\begin{array}{l}\text { Department of } \\
\text { Geoinformatics }\end{array}$ & Austria \\
\hline $\begin{array}{l}\text { Geographische } \\
\text { Informationssysteme } \\
\text { (GIS) }\end{array}$ & both & 36 & ECTS & yes & University of Salzburg & $\begin{array}{l}\text { Department of } \\
\text { Geoinformatics }\end{array}$ & Austria \\
\hline $\begin{array}{l}\text { Geospatial } \\
\text { Information Systems }\end{array}$ & undergraduate & 18 & $\begin{array}{l}\text { Australian } \\
\text { Unit } \\
\end{array}$ & & $\begin{array}{l}\text { University of South } \\
\text { Australia }\end{array}$ & $\begin{array}{l}\text { School of Natural and } \\
\text { Built Environments }\end{array}$ & Australia \\
\hline
\end{tabular}


Most Minors are offered at undergraduate level. Fewer universities admit both undergraduate and graduate students to such programs. Many universities issue a certificate to document the completion of a Minor program of study, in which case it is then clearly stated on the program's website; see, for example, Figure 2 ("Geographic Information Science (GIS) minor" at Penn State University, 2015). Such an explicit qualification adds value and raises the attractiveness of a program.

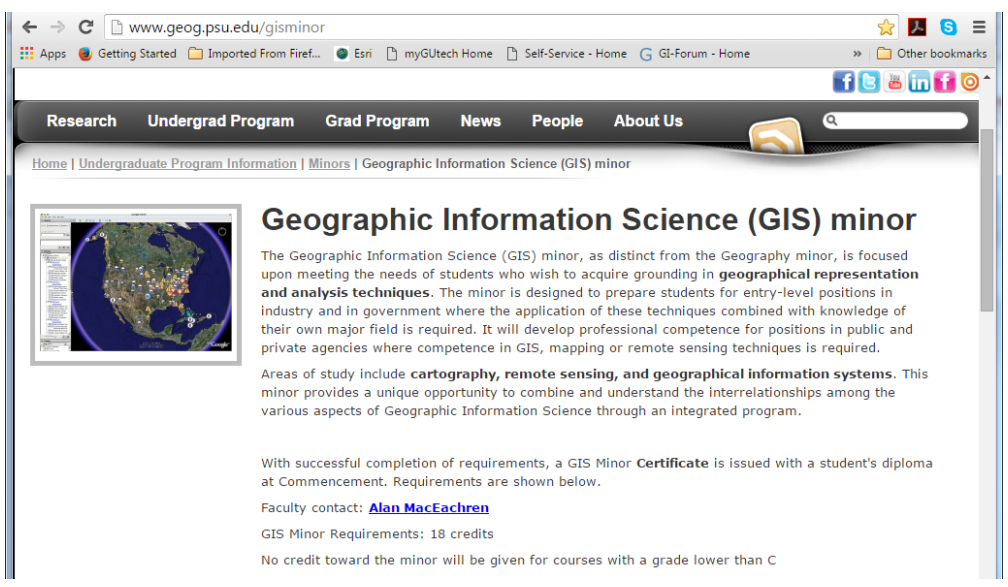

Figure 2: Website of the GIScience Minor at Penn State University, with program specifications.

\section{Structure of Minors}

All sample programs have the same structure: they consist of core courses and one or more elective courses (Figure 3 and Figure 4). Each of these course groups is defined as comprising a set of courses and a number of credits to earn. Core courses are mandatory; choice of electives is usually structured - for example, in the US choice may be between lower and upper level courses, by theme or discipline. 
Car \& Strobl

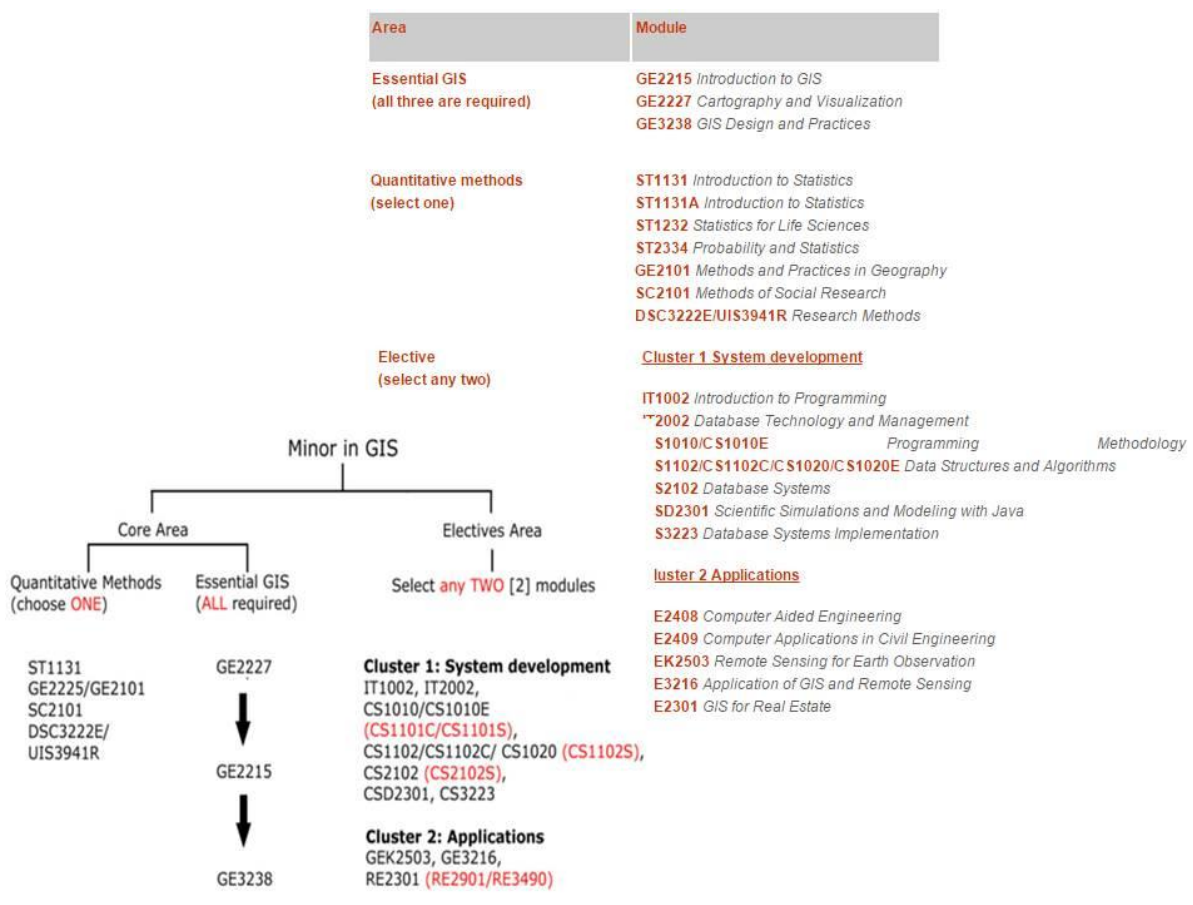

Figure 3: Structure of GIS Minors programs: example from the National University of Singapore.

\section{GIS@ McMaster 2015-2016}

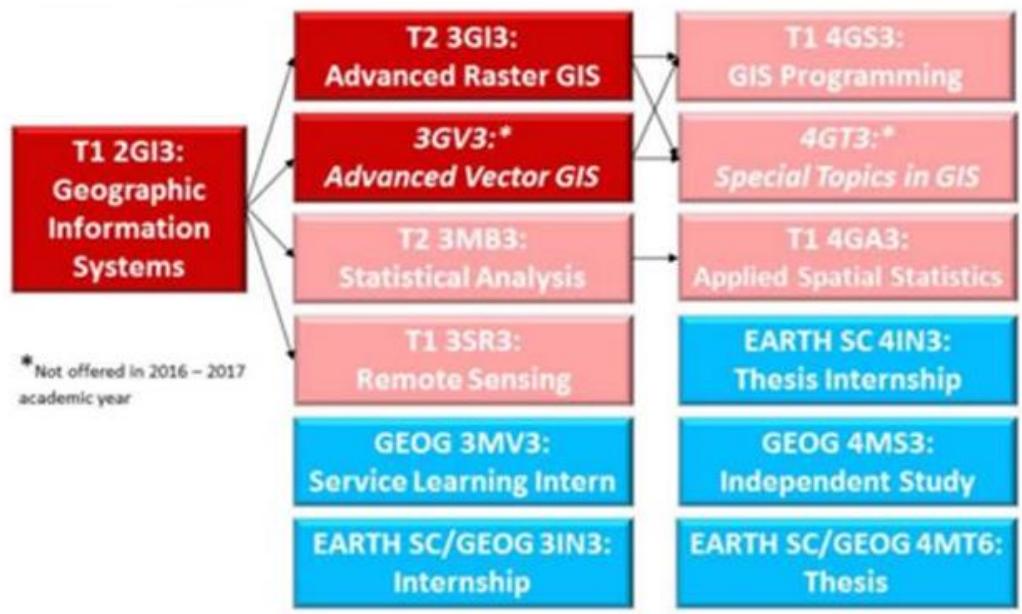

Figure 4: Structure of GIS Minors programs: example from McMaster University. 
Any comparison of Minors based on the total number of credit points is rather difficult due to the lack of standardized, compatible credit systems, particularly outside Europe. The European Higher Education Area, however, seems to be an exception due to the use of ECTS, thanks to which credits can still be used as a measure for the comparison of programs. One way to do this is to calculate a ratio between credits for core and elective elements. Table 3 shows ratios of the sample programs, which vary considerably. Another way is to express the Minors' total credits relative to the credits needed for an undergraduate program. For example, two European Minors equal roughly one semester, or 1/6 to $1 / 8$ of an undergraduate degree. This is now comparable to at least some US programs, like the UCSB Spatial Science program (Kuhn, 2015).

Table 3: GIS Minor programs: credit ratio between core courses and electives ( $\mathrm{CP}=$ Credit Point)

\begin{tabular}{|c|c|c|c|c|c|c|}
\hline Program name & University & $\begin{array}{l}\text { CP } \\
\text { system }\end{array}$ & $\begin{array}{l}\mathrm{CP} \\
\text { value }\end{array}$ & $\begin{array}{l}\mathrm{CP} \\
\text { core }\end{array}$ & $\begin{array}{l}\mathrm{CP} \\
\text { elective }\end{array}$ & $\begin{array}{l}\text { CP_core : } \\
\text { CP_elective }\end{array}$ \\
\hline $\begin{array}{l}\text { Minor in Geographic } \\
\text { Information Systems }\end{array}$ & $\begin{array}{l}\text { National } \\
\text { University of } \\
\text { Singapore }\end{array}$ & $\begin{array}{l}\text { MC } \\
\text { (Module } \\
\text { Credit) }\end{array}$ & 24 & 16 & 8 & $67: 33$ \\
\hline $\begin{array}{l}\text { UCSB Academic } \\
\text { Minor in Spatial } \\
\text { Studies }\end{array}$ & $\begin{array}{l}\text { University of } \\
\text { California, } \\
\text { Santa Barbara }\end{array}$ & $\begin{array}{l}\text { US credit, } \\
\text { university- } \\
\text { dependent }\end{array}$ & 24 & 4 & 20 & $16: 84$ \\
\hline $\begin{array}{l}\text { USC Spatial Studies } \\
\text { Minor }\end{array}$ & $\begin{array}{l}\text { University of } \\
\text { Southern } \\
\text { California } \\
\end{array}$ & $\begin{array}{l}\text { US credit, } \\
\text { university- } \\
\text { dependent }\end{array}$ & 20 & 12 & 8 & $60: 40$ \\
\hline $\begin{array}{l}\text { Penn State Geographic } \\
\text { Information Science } \\
\text { (GIS) Minor }\end{array}$ & $\begin{array}{l}\text { Pennsylvania } \\
\text { State } \\
\text { University } \\
\text { (PennState) }\end{array}$ & $\begin{array}{l}\text { US credit, } \\
\text { university- } \\
\text { dependent }\end{array}$ & 18 & 3 & 15 & $16: 84$ \\
\hline $\begin{array}{l}\text { Minor program in } \\
\text { Geographic } \\
\text { Information Science } \\
(\mathrm{BSc})(\mathrm{BA})\end{array}$ & $\begin{array}{l}\text { University of } \\
\text { Toronto } \\
\text { Scarborough }\end{array}$ & $\begin{array}{l}\text { Canadian } \\
\text { credit, } \\
\text { university- } \\
\text { dependent }\end{array}$ & 4 & 2 & 2 & $50: 50$ \\
\hline McMU GIS Minor & $\begin{array}{l}\text { McMaster } \\
\text { University, } \\
\text { Hamilton }\end{array}$ & $\begin{array}{l}\text { Canadian } \\
\text { credit, } \\
\text { university- } \\
\text { dependent }\end{array}$ & 24 & 6 & 18 & $33: 77$ \\
\hline $\begin{array}{l}\text { Joint National } \\
\text { Geoinformation Minor }\end{array}$ & $\begin{array}{l}\text { Free } \\
\text { University } \\
\text { Amsterdam }\end{array}$ & ECTS & 30 & 12 & 18 & $40: 60$ \\
\hline $\begin{array}{l}\text { Geographische } \\
\text { Informationssysteme } \\
\text { (GIS) }\end{array}$ & $\begin{array}{l}\text { University of } \\
\text { Salzburg }\end{array}$ & ECTS & $24-36$ & 30 & 6 & $83: 17$ \\
\hline $\begin{array}{l}\text { Geospatial } \\
\text { Information Systems }\end{array}$ & $\begin{array}{l}\text { University of } \\
\text { South } \\
\text { Australia }\end{array}$ & $\begin{array}{l}\text { Australian } \\
\text { Unit }\end{array}$ & 18 & 9 & 9 & $50: 50$ \\
\hline
\end{tabular}

A high percentage of electives might be seen as an indicator of intended flexibility, but it can also be seen as reflecting weakly-defined learning outcomes and competences, or as a pragmatic "harvesting" of existing courses to accumulate towards a certificate. Any Minor 
that is significantly less than a full semester workload might not be taken seriously as an addon qualification.

\section{Content analysis of Minors}

The majority of sample program descriptions contain more or less explicitly formulated methodological and technical competencies. For example, Schulze et al. (2013) identified the following three competences as those essential for GIS-related learning in higher education: (1) GIS-related knowledge and skills, (2) spatial thinking, and (3) problem solving. GISrelated knowledge and skills include: conceptual foundations, geodata acquisition, mapping, cartography and/or visualization, spatial analysis, and GI technologies (especially Remote Sensing and GIS). University of Southern California Spatial Studies Minor offers an example of a statement of learning objectives (Kemp \& Goodchild, 1991) that explicitly mentions some of these:

- "Learn how geographically referenced data can be gathered and organized to support a large number and variety of collaborative projects

- Learn how to perform spatial analysis and modelling to create new knowledge across a variety of disciplines and application domains

- Learn how to make maps that synthesize and communicate new knowledge about places and people."

Problem-solving competency refers to "multi-dimensional representations of information to help structure problems, find answers, and express solutions". It is exercised in courses specifically related to GIS applications, internships and project courses. For example, Penn State, McMaster University, the Free University Amsterdam and the University of Salzburg offer such courses.

Spatial thinking is a problem-solving skill applied in many different disciplines (Kerski, 2014). In GIS Minor programs, students from different disciplines learn how to "visualize and interpret relationships through space" and so "reveal the interdisciplinary nature of many problems" (Spatial Studies Minor, University of Redlands). Spatial cognition and reasoning to solve complex problems are one of the three focuses of the UCSB Minor in Spatial Studies.

These competences are reflected in the individual courses. Table 4 lists topics taught across the Minor programs. Individual course descriptions were read selectively, mainly where course names were cryptic. At this stage, no course-level learning objectives were further investigated. 
Table 4: Course topics taught in the sample GIS Minors

\begin{tabular}{|l|l|}
\hline Core & Electives \\
\hline Foundations of GIS [Science | Systems] & IT-related courses, programming \\
$\begin{array}{l}\text { Cartography and Visualization [maps | mapping | } \\
\text { topographic and thematic cartography | coordinate } \\
\text { systems] }\end{array}$ & Applications \\
Analysis [Spatial | Geographical] & Remote sensing \\
Quantitative methods [statistics] & Cartography \\
Geodata acquisition & Image analysis \\
Geodesign & GI Tools \\
Research methods & Quality of Geodata \\
GI Technologies [remote sensing, GPS] & Web dissemination \\
& Project | Internship \\
& Discipline-specific courses \\
\hline
\end{tabular}

Generally speaking, Minors tend to focus on basic topics and practical skill sets, as these secondary programs are intended for combination with a variety of Majors. Several programs address the specific competences relevant for the job market. Some examples are GIS specialists in industry, government and academia.

Information gathered from the analysis of the structure and contents of programs can serve as a basis for the curriculum design of a Minor in GIS.

\section{Body of Knowledge for GIS Minors - Proposal}

"We teach mathematics and language skills to everyone - should we not also be teaching a subset of GIS\&T to everyone?," asked Michael Goodchild in the Foreword to GIS\&T in bigher education: challenges for educators, opportunities for education (Foote et al., 2012, p. xvi). In the context of GIS Minors, everyone can be understood as students in Higher Education interested in a spatial approach. Some disciplines, such as ecology and planning, are traditionally considered "customers", while others increasingly stress the spatial view, or compare for example the "spatial turn" in the humanities and social sciences. In this study, we provide a first attempt to identify this subset of GIS\&T and propose a Body of Knowledge for GIS Minors using the following sources as the very basis:

I. GIS\&T BoK (DiBiase et al., 2006)

II. BoK2 project, hereafter referred to as the "Wilson report" (Wilson, 2014)

III. GI-N2K assessment of workforce demand to shape GIS\&T (Wallentin et al., 2015) (At the time of writing, the GI-N2K European BoK is still under construction - Car \& Strobl).

IV. GIS Minor curricula analysis (as presented in this paper) 
The rationale for the choice of documents II and III is that they all rate the core Knowledge Areas (KAs) as similarly important (Wallentin et al., 2015, p. 13, Figure 7).

One approach is to select a subset of KAs and their constituent Units from GIS\&T BoK as a resource for defining the course content for GIS Minors (I). The input from the BoK2 project (II) and the results from the workforce demand assessment (III), as well as the input from the GIS Minor curricula analysis (IV) presented in the "Analysis of the sample programs" section of this study, are used to define the following selection criteria.

\section{Selection criteria}

\section{Criterion 1: GIS\&T BoK common core}

GIS\&T BoK's common core identifies a body of fundamental knowledge in which any graduate of a GIS\&T undergraduate program should demonstrate a level of mastery (DiBiase et al., 2006, p. 34). For example, the Knowledge Area "Analytical Methods" (AM) consists of 12 Units, of which only 3 Units (AM3, AM4 and AM5) belong to the common core:

Unit AM1 Academic and analytical origins

Unit AM2 Query operations and query languages

Unit AM3 Geometric measures

Unit AM4 Basic analytical operations

Unit AM5 Basic analytical methods

Unit AM6 Analysis of surfaces

Unit AM7 Spatial statistics

Unit AM8 Geostatistics

Unit AM9 Spatial regression and econometrics

Unit AM10 Data mining

Unit AM11 Network analysis

Unit AM12 Optimization and location-allocation modeling

Consequently, we consider a subset of $\mathbf{9}$ KAs and $\mathbf{2 6}$ of their constituent core Units, together with all of their Topics, as the main resource for specifying course content for GIS Minors. Note that only the KA "Geocomputation" is omitted because none of its Topics belong to the common core.

\section{Criterion 2: BoK2 project}

Ratings of the BoK Topics with respect to their importance in the Wilson Report are used to further reduce the common core BoK. The importance of each Topic was rated as 1 high importance, 2 high to moderate importance, 3 moderate importance, 4 moderate to low importance, 5 low importance, or 6 no longer relevant. Topics shown in red (Tables 6 and 7) are those for which at least one response included a rating of 5 or 6 (Wilson, 2014, pp. 5769, Table A3.1 - A.3.10).

If we consider course content of a GIS Minor to be the "core of the common core" of BoK, it would be appropriate to expect candidate topics for a GIS Minor course to be of high importance - i.e., rated 1. The mean scores for the KAs range from 1.70 to 2.78 , with the 
highest-rated topics rated less than 2 - i.e. high-to-moderate to high importance (Wilson, 2014, p. 9., Table 2). All core topics rated as at least as high-to-moderate to high $(<2)$ were kept in the BoK course content selection.

Descriptions of Topics and their learning objectives in GIS\&T BoK were also rated and achieved scores of $2.3-3.0$. As 2 means "satisfactory" and 3 "needs updating", the learning objectives for the Topics need to be revised (Wilson, 2014, pp. 70-81, Table A4.1 - A4.10). This is one of the reasons why at this stage our proposal does not include the learning objective level.

\section{Criterion 3: GIS Minor content - choice of themes}

The choice of GI-relevant themes draws primarily on findings in sources III and IV. Wallentin et al. (2015, pp. 11-12 and Figure 6) identify map-making, spatial analysis and data management as those topics that continue to dominate GIS\&T professionals' daily activities. The following KAs were especially indicated in connection to existing or desired competencies. Acquiring, processing and managing geodata (i.e. data handling) is mainly covered in GD (Geospatial Data). Programming and application development are for the most part addressed in DA (Design Aspects). Web development aspects are covered in CV (Cartography and Visualization), DM (Data Modelling) and AM Analytical Methods combined. Applying theoretical knowledge to real-world problems is emphasized as one of the major deficiencies, together with programming skills. Table 5 shows an example of how all three criteria were applied to identify candidates for the final selection.

Table 5: The Knowledge Area "Analytical Methods" (AM) is used as an example of how Criterion 1 Criterion 3 influenced the choice of Topics. In the column "Rate of importance", values are indicated if equal to or greater than 2 but less than 3, or if red (where at least one response evaluated a Topic being of low importance or no longer relevant); an empty cell indicates a value of less than 2 (Wilson report).

\begin{tabular}{|c|c|c|c|c|c|c|}
\hline \multicolumn{4}{|l|}{ BoK } & \multirow{2}{*}{$\begin{array}{l}\text { Rate of } \\
\text { importance }\end{array}$} & \multirow{2}{*}{$\begin{array}{l}\text { Compe } \\
\text {-tency }\end{array}$} & \multirow{2}{*}{ Reference } \\
\hline $\begin{array}{l}\text { Knowled } \\
\text { ge Area }\end{array}$ & $\begin{array}{l}\text { Cor } \\
\text { e }\end{array}$ & Units & Topics & & & \\
\hline \multirow{9}{*}{$(\mathrm{AM})$} & \multirow{6}{*}{$\mathrm{C}$} & \multirow{6}{*}{$\begin{array}{l}\text { AM3 Geometric } \\
\text { measures }\end{array}$} & 3-1 Distances and Length & & & \\
\hline & & & 3-2 Direction & 2.05 & & \\
\hline & & & 3-3 Shape & & & \\
\hline & & & 3-4 Area & 2.00 & & \\
\hline & & & $\begin{array}{l}\text { 3-5 Proximity and } \\
\text { Distance Decay }\end{array}$ & & & \\
\hline & & & $\begin{array}{l}\text { 3-6 Adjacency and } \\
\text { Connectivity }\end{array}$ & & & \\
\hline & \multirow{3}{*}{$\mathrm{C}$} & \multirow{3}{*}{$\begin{array}{l}\text { AM4 Basic } \\
\text { analytical } \\
\text { operations }\end{array}$} & 4-1 Buffers & 1.70 & & \\
\hline & & & 4-2 Overlay & & & \\
\hline & & & 4-3 Neighbourhoods & & & \\
\hline
\end{tabular}


Car \& Strobl

\begin{tabular}{|c|c|c|c|c|c|}
\hline & & 4-4 Map Algebra & & & \\
\hline \multirow{8}{*}{ C } & \multirow{8}{*}{$\begin{array}{l}\text { AM5 Basic } \\
\text { analytical methods }\end{array}$} & 5-1 Point Pattern Analysis & & & \\
\hline & & $\begin{array}{l}5-2 \text { Kernels and Density } \\
\text { Estimation }\end{array}$ & & & \\
\hline & & $\begin{array}{l}\text { 5-3 Spatial Cluster } \\
\text { Analysis }\end{array}$ & & & \\
\hline & & 5-4 Spatial Interaction & 2.26 & & \\
\hline & & $\begin{array}{l}\text { 5-5 Analysing } \\
\text { Multidimensional } \\
\text { Attributes }\end{array}$ & 2.18 & & \\
\hline & & $\begin{array}{l}\text { 5-6 Cartographic } \\
\text { Modelling }\end{array}$ & 2.52 & & \\
\hline & & $\begin{array}{l}5-7 \text { Multicriteria } \\
\text { Evaluation }\end{array}$ & & & \\
\hline & & $\begin{array}{l}\text { 5-8 Spatial Process } \\
\text { Models }\end{array}$ & & & \\
\hline & \multirow{2}{*}{ AM10 Data Mining } & $\begin{array}{l}\text { AM10-2 Data Mining } \\
\text { approaches }\end{array}$ & & $\begin{array}{l}\text { data } \\
\text { mining }\end{array}$ & $\begin{array}{l}\text { Wallentin et } \\
\text { al., } 2015\end{array}$ \\
\hline & & $\begin{array}{l}\text { AM10-3 Knowledge } \\
\text { discovery }\end{array}$ & 2.06 & $\begin{array}{l}\text { data } \\
\text { mining }\end{array}$ & $\begin{array}{l}\text { Wallentin et } \\
\text { al., } 2015\end{array}$ \\
\hline
\end{tabular}

In general, existing GIS Minors tend to focus on basic topics and include set(s) of practical skills (see Table 4). These are: concepts of GIScience; geodata acquisition; spatial analysis; mapping, cartography and visualization; GI-Technologies with special focus on remote sensing, GPS and GISystems; and GIS application (commonly, more the "application" than the "development" aspect).

There is considerable overlap among the topics, and we therefore propose the following set as the common denominator: concepts of GIScience, geodata acquisition, spatial analysis, cartography and visualization, GI-Technologies incl. remote sensing, GPS and GISystems, and GIS applications.

\section{A proposal for GIS Minor core content}

A specification for the course content of a GIS Minor based on Criteria 1-3 defined above is proposed in Table 6. The core content and competencies are strongly related to GIS knowledge and skills, one of the essential competencies for GIS learning in Higher Education (Schulze et al., 2013).

Table 6: Proposal for course content: selection of BoK Units and Topics based on Criteria 1-3. Topics shown in red are those for which at least one response was rated as of low importance, or as no longer relevant.

\begin{tabular}{|l|l|l|}
\hline $\begin{array}{l}\text { BoK } \\
\text { Knowledge } \\
\text { Areas }\end{array}$ & BoK Units & BoK Topics \\
\hline \multirow{4}{*}{$\begin{array}{l}\text { Analytical } \\
\text { Methods (AM) }\end{array}$} & $\begin{array}{l}\text { AM3 Geometric } \\
\text { measures }\end{array}$ & 3-1 Distances and Length \\
\cline { 2 - 3 } & 3-3 Shape \\
\cline { 2 - 3 } & AM4 Basic analytical & 4-1 Buffers \\
\cline { 2 - 3 } & &
\end{tabular}


Car \& Strobl

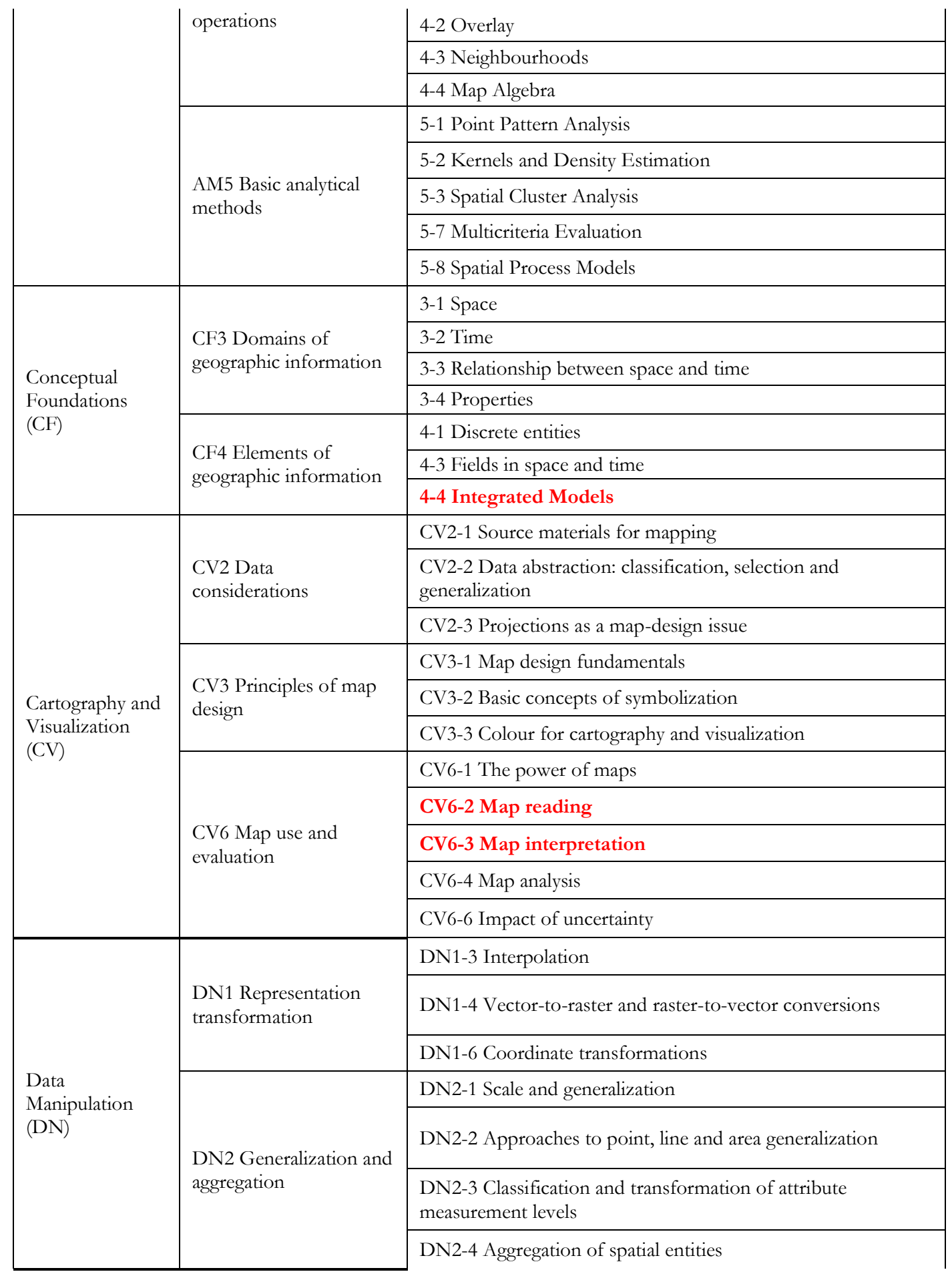


Car \& Strobl

\begin{tabular}{|c|c|c|}
\hline \multirow{23}{*}{$\begin{array}{l}\text { Geospatial Data } \\
\text { (GD) }\end{array}$} & \multirow{2}{*}{ GD1 Earth geometry } & GD1-2 Approximating the Earth's shape with geoids \\
\hline & & GD1-3 Approximating the geoid with spheres and ellipsoids \\
\hline & \multirow{2}{*}{$\begin{array}{l}\text { GD3 Georeferencing } \\
\text { systems }\end{array}$} & GD3-1 Geographic coordinate system \\
\hline & & GD3-2 Plane coordinate systems \\
\hline & \multirow{2}{*}{ GD4 Datums } & GD4-1 Horizontal datums \\
\hline & & GD4-2 Vertical datums \\
\hline & \multirow{4}{*}{ GD5 Map projections } & GD5-1 Map projection properties \\
\hline & & GD5-2 Map projection classes \\
\hline & & GD5-3 Map projection parameters \\
\hline & & GD5-4 Georegistration \\
\hline & \multirow{5}{*}{ GD6 Data quality } & GD6-1 Geometric accuracy \\
\hline & & GD6-2 Thematic accuracy \\
\hline & & GD6-3 Resolution \\
\hline & & GD6-4 Precision \\
\hline & & GD6-5 Primary and secondary sources \\
\hline & $\begin{array}{l}\text { GD7 Land surveying } \\
\text { and GPS }\end{array}$ & GD7-3 Global Positioning System \\
\hline & \multirow{2}{*}{$\begin{array}{l}\text { GD10 Aerial imaging } \\
\text { and photogrammetry }\end{array}$} & GD10-1 Nature of aerial image data \\
\hline & & GD10-2 Platforms and sensors \\
\hline & \multirow{3}{*}{$\begin{array}{l}\text { GD11 Satellite and } \\
\text { shipboard remote } \\
\text { sensing }\end{array}$} & GD11-1 Nature of multispectral image data \\
\hline & & GD11-2 Platforms and sensors \\
\hline & & GD11-3 Algorithms and processing \\
\hline & \multirow{2}{*}{$\begin{array}{l}\text { GD12 Metadata, } \\
\text { standards and } \\
\text { infrastructures }\end{array}$} & GD12-1 Metadata \\
\hline & & GD12-6 Spatial data infrastructures \\
\hline $\begin{array}{l}\text { Design Aspects } \\
\text { (DA) }\end{array}$ & DA4 Database design & DA4-2 Conceptual model \\
\hline \multirow{6}{*}{$\begin{array}{l}\text { Data Modelling } \\
\text { (DM) }\end{array}$} & \multirow{3}{*}{$\begin{array}{l}\text { DM3 Tessellation data } \\
\text { models }\end{array}$} & DM3-1 Grid representations \\
\hline & & DM3-2 The raster model \\
\hline & & DM3-6 Resolution \\
\hline & \multirow{3}{*}{$\begin{array}{l}\text { DM4 Vector and object } \\
\text { data models }\end{array}$} & DM4-1 Geometric primitives \\
\hline & & DM4-3 The topological model \\
\hline & & DM4-5 The network model \\
\hline
\end{tabular}




\section{Summary, Discussion and Outlook}

In this study we have addressed the lack of a framework for comparison of GIS Minors and their standardized core content. Their comparison is challenging due to the diversity of academic environments, as reflected in their individual credit values and learning outcomes.

All GIS Minors analysed have a similar, specific program structure and content (in terms of topics covered) and these were used as the basis for our comparison. We made three main observations. Firstly, most of the programs consist of a combination of core and elective course(s), but the proportion of electives varies greatly. Secondly, to be taken as a serious add-on qualification, a Minor program should require roughly a full semester workload. Thirdly, in general Minors tend to focus on general topics and practical skill sets, including the foundations of GIScience, data acquisition, spatial analysis, mapping and visualization, as well as the use of GISystems, GPS and remote sensing.

We combined these findings with the outcomes of recent work on redesigning the GIS\&T BoK (reported in Wallentin et al., 2015; Wilson, 2014) and derived a set of criteria for specifying course content for GIS Minors. Using the content of GIS\&T BoK as the main source for a model curriculum, we selected a set of topics as the basis for the design of a Body of Knowledge of GIS Minors.

The results from this study are just a starting point for debate among GIS\&T educators, researchers and practitioners, which will ultimately lead to a full-blown BoK for Minors. In addition to contributing to the revision of the content of the BoK which is clearly needed in order to keep up with trends in the profession and its needs, the debate is expected to:

- help formulate core competencies acquired through a GIS-Minor

- identify the "core" topics in which any GIS Minor student needs to demonstrate some level of mastery

- agree upon comparable workloads and shares of electives between GIS Minors

- revise existing learning objectives and define new ones at the Topic level.

The overall competency level that students should have already when they are about to start undergraduate study is worth further exploration, particularly where problem-solving and critical and creative spatial thinking are concerned. Lastly, differences with regard to GI core competences appropriate for different fields also deserve further discussion. For example, do Minors in GIS for forestry all require map-reading skills? Might urban GIS programs ignore remote sensing? Discussion of such questions would take the debate beyond pedagogical diversity and contribute to a better understanding of the diversity of GIS in general.

\section{Acknowledgements}

The authors appreciate the reviewers' comprehensive comments highly. 


\section{References}

Bowen, G. A. (2009). Document Analysis as a Qualitative Research Method. Qualitative Research Journal, 9(2), 27-40. doi: 10.3316/QRJ0902027

Bryman, A. (2012). Social Research Methods (4th edition): Oxford University Press.

DeMers, M. N. (2009). Using Intended Learning Objectives to Assess Curriculum Materials: the UCGIS Body of Knowledge. Journal of Geography in Higher Education, 33(sup1), S70-S77. doi: 10.1080/03098260903033980

DiBiase, D., DeMers, M., Johnson, A., Kemp, K., Luck, A. T., Plewe, B., \& Wentz, E. (Eds.). (2006). Geographic Information Science \& Technology Body of Knowledge (1st edition). Washington, D.C.: Association of American Geographers.

ERASMUS+. (2015). ECTS Users' Guide 2015. UK: European Union.

Foote, K. F., Unwin, D. J., Tate, N. J., \& DiBiase, D. (2012). GIS\&T in higher education: challenges for educators, opportunities for education. In D. J. Unwin, K. E. Foote, N. J. Tate \& D. DiBiase (Eds.), Teaching Geographic Information Science and Technology in Higher Education (pp. 3-15): Wiley-Blackwell.

Geographic Information Science (GIS) minor. (2016). Retrieved 03.02.2016, from http://www.geog.psu.edu/gisminor

Geographic Information Science (GIS) minor at PennState University. (2015). Retrieved 10.04.2016, from http://www.geog.psu.edu/gisminor

Goodchild, M. F. (2010). Twenty years of progress: GIScience in 2010. JOSIS Journal of Spatial Information Science, 2010(1), 3-20. doi: doi:10.5311/JOSIS.2010.1.2

Kemp, K. K., \& Goodchild, M. F. (1991). Developing a curriculum in geographic information systems: the national center for geographic information and analysis core curriculum project. Journal of Geography in Higher Education, 15(2), 123-134. doi: 10.1080/03098269108709142

Kerski, J. (2014). 10 Skills the Future Workforce will Need: Connections to GIS. Retrieved from http://blogs.esri.com/esri/gisedcom/2014/10/24/10-skills-the-future-workforce-will-needconnections-to-gis/?utm_source=esri

Kuhn, W. (2015). [Spatial Studies Minor at UCSB - value of the program in credits].

masterportal. (2015). All You Need to Know about Academic Credit in Australia. Retrieved 03.02.2015, from http://www.mastersportal.eu/articles/1115/all-you-need-to-know-aboutacademic-credit-in-australia.html

Minor in GIS at the National University of Singapore. (2013). Retrieved 10.04.2016, from http://www.fas.nus.edu.sg/geog/undergrads/minor_gis.htm

Norris, J. (2015). Future Trends in geospatial information management: the five to ten year vision, Second Edition December 2015 (Second Edition ed.): United Nations Committee of Experts on Global Geospatial Information Management (UN-GGIM).

Prager, S. (2012). Using the GIS\&T Body of Knowledge for curriculum design: Different design for different contexts. In D. Unwin, K. E. Foote, N. J. Tate \& D. DiBiase (Eds.), Teaching geographic information science and technology in higher education (pp. 63 - 80). Chichester: Wiley-Blackwell.

Prager, S., \& Plewe, B. (2009). Assessment and evaluation of GIScience curriculum using the geographic information science and technology body of knowledge. Journal of Geography inHigher Education, 33(1), 46 - 69.

Schulze, U., Kanwischer, D., \& Reudenbach, C. (2013). Essential competences for GIS learning in higher education: a synthesis of international curricular documents in the GIS\&T domain. Journal of Geography in Higher Education, 37(2), 257-275. doi: 10.1080/03098265.2012.763162

Strobl, J. (2008). Digital Earth Brainware. A Framework for Education and Qualification Requirements. In J. Schiewe (Ed.), Geoinformatics paves the Highway to Digital Earth. "gireports" des Instituts für Geoinformatik und Fernerkundung der Universität Osnabrück. 
Studienergaenzungen und Schwerpunkte. (2016). from http://www.unisalzburg.at/index.php?id $=33271$

USNEI. (2008). Structure of the U.S. Education System: Credit Systems. Retrieved from https://www2.ed.gov/about/offices/list/ous/international/usnei/us/credits.doc.

Verfaillie, E., De Wit, B., Kellens, W., Maddens, R., Van de Weghe, N., Vanopbroeke, V., . . . De Maeyer, P. (2012). A questionnaire to evaluate the GI job market in Flanders: first findings. Paper presented at the EUGISES 2012, Leuven, Belgium.

Wallentin, G., Hofer, B., \& Traun, C. (2015). Assessment of Workforce Demands to Shape GIS\&T Education. Transactions in GIS, 19(3), 439-454. doi: 10.1111/tgis.12148

Wilson, J. P. (2014). Geographic Information Science \& Technology: Body of Knowledge 2.0 Project. Final Report: University Consortium for Geographic Information Science. 